\title{
EKSISTENSI DAN STRATEGI ADAPTASI KOMUNITAS ADAT DI JAWA BARAT
}

\author{
Oleh Toto Sucipto
}

Balai Pelestarian Sejarah dan Nilai Tradisional Bandung

Jalan Cinambo No. 136 Ujungberung Bandung

Telp./Fax (022) 7804942 Email : totosucipto@ymail.com

Naskah diterima: 15 Juni 2011

Naskah disetujui: 1 Agustus 2011

\begin{abstract}
Abstrak
Di Jawa Barat terdapat komunitas adat yang konsentrasi warganya tersebar di beberapa pemukiman yang disebut kampung atau kampung gede (kampung induk). Secara umum dapat diungkapkan bahwa warga komunitas adat yang ada di Jawa Barat tersebut mendukung kebudayaan Sunda, yaitu yang sehari-harinya mempergunakan bahasa Sunda dan merupakan masyarakat terbuka yang mudah sekali menerima pengaruh dari luar, tetapi juga kemudian menyerap pengaruh itu sedemikian rupa sehingga menjadi miliknya sendiri. Yang menjadi pertanyaan adalah, apakah warga komunitas adat di Jawa Barat yang termasuk pendukung kebudayaan Sunda ini mudah menerima pengaruh luar seperti masyarakat Sunda umumnya? Kajian menarik tentang komunitas adat antara lain mencuatkan kenyataan bahwa warga komunitas adat selalu berupaya patuh terhadap kasauran karuhun (perkataan/wasiat para leluhur) sehingga dinamika kebudayaan mereka agak sulit terdeteksi dengan mudah. Komunitas adat berusaha menyesuaikan diri dengan lingkungan alam dan berupaya mempertahankan kondisi lingkungan alamnya dengan tetap mentaati aturan adat warisan para leluhur sehingga setiap komunitas adat memiliki ciri khas yang membedakannya dengan masyarakat lain. Para pendahulu mereka (leluhur) mengembangkan aturan-aturan adat yang direalisasikan pada beberapa tabu/pamali/larangan/buyut. Aturan-aturan adat tersebut mempunyai makna atau fungsi yang sangat luas. Aturan tersebut juga berfungsi sebagai mekanisme kontrol dalam kebudayaan yang menahan dilakukannya eksploitasi alam secara semena-mena, membuat masyarakat tetap sederhana, tidak hidup berlebihan, dan tetap memegang prinsip kebersamaan sehingga keseimbangan lingkungan, baik fisik maupun sosial, dapat dipertahankan. Mekanisme itu diselimuti dengan sanksi moral, sehingga keadaan lingkungan relatif stabil dalam jangka waktu relatif lama.
\end{abstract}

Kata kunci : komunitas adat, tabu, mekanisme kontrol, eksistensi, strategi adaptasi 


\section{Abstract}

There are many adat communities in West Java which concentrated in clusters called kampung or kampung gede (main village). Generally, those adat communities are part of Sundanese culture and use Sundanese language in their daily life. They also openly received external influences and absorb them as their own. This research tries to seek whether these communities can easily receive those external influences like any other Sundanese. This actually would be interesting because adat communities are usually obedient to the rules made by their ancestors, especially some taboos. The rules have vast meaning and funtions. They are important in controlling the use of natural resources, and teach the community to live in a modest life. The conclusion is that the rules are still important in today's life as well as for the future.

Keywords: adat communities, taboos, control mechanism, existence, adaptation strategy

\section{A. PENDAHULUAN}

Pada umumnya, kebudayaan dapat dikatakan bersifat adaptif karena kebudayaan itu melengkapi manusia dengan cara-cara penyesuaian diri pada kebutuhan-kebutuhan fisiologis dari badan mereka sendiri, penyesuaian pada lingkungan yang bersifat fisik-geografis, maupun lingkungan sosialnya. Kenyataan bahwa banyak kebudayaan bertahan malah berkembang menunjukkan bahwa kebiasaan-kebiasaan yang dikembangkan oleh suatu masyarakat, disesuaikan dengankebutuhan-kebutuhan tertentudari lingkungannya. Ini tidak mengherankan, karena kalau sifat-sifat budaya tidak disesuaikan kepada beberapa keadaan tertentu, kemungkinan masyarakat untuk bertahan akan berkurang. Tiap-tiap adat yang meningkatkan ketahanan suatu masyarakat dalam lingkungan tertentu merupakan adat yang dapat disesuaikan (Ember \& Ember dalam T.O. Ihromi, 1980: 28).

Sebagaimana kebudayaan itu merupakan suatu penyesuaian pada lingkungan fisik dan kebutuhankebutuhan biologis, kebudayaan juga merupakan suatu penyesuaian pada lingkungan sosial. Perubahan-perubahan ekonomi dan kesempatan dalam bidang sosial merangsang munculnya bentukbentuk kelakuan baru yang memecahkan masalah-masalah baru, kemudian bisa menjadi pola-pola yang secara berulang terwujud dan pada akhirnya menjadi milik bersama. Pola-pola kelakuan, norma-norma, dan aspirasi-aspirasi terwujud dalam melakukan adaptasi, dan adanya kebudayaan bermula pada adanya respon-respon terhadap situasisituasi seperti kondisi ekonomi, sosial, lingkungan, dan kondisi-kondisi lainnya.

Kebiasaan atau kelakuan yang terpolakan yang ada dalam masyarakat tertentu merupakan penyesuaian masyarakat itu terhadap lingkungannya, tetapi cara penyesuaian itu bukan berarti mewakili semua cara penyesuaian yang mungkin diadakan oleh masyarakat lain dalam kondisi yang sama. Dengan kata lain, masyarakat manusia yang berlainan akan memilih cara-cara penyesuaian yang berbeda terhadap keadaan yang sama. 
Dalam The Evolution of Culture (1959), Leslie A. White mengungkapkan, kebudayaan merupakan kumpulan tiga komponen, yaitu komponen tekno-ekonomis, komponen sosial, dan komponen ideologi. Aspek teknoekonomis kebudayaan diberinya pengertian sebagai cara yang digunakan oleh para pendukung suatu kebudayaan untuk menghadapi lingkungan mereka. Aspek inilah yang kemudian menentukan aspek sosial dan ideologi kebudayaan.

\section{B. HASIL DAN BAHASAN}

Komunitas Adat di Jawa Barat: Eksistensi dan Strategi Adaptasi

Sejak berdiri pada tahun 1990 hingga tahun 2011, Balai Pelestarian Sejarah dan Nilai Tradisional Bandung telah mendokumentasikan beberapa komunitas adat di Jawa Barat, Banten, DKI Jakarta, dan Lampung. Khusus di Jawa Barat, terdapat komunitas adat yang pemukimannya antara lain di Kampung Naga-Kabupaten Tasikmalaya, Kampung Gede Kasepuhan Ciptagelar di Kabupaten Sukabumi, Kasepuhan Sinaresmi di Kabupaten Sukabumi, Kasepuhan Ciptamulya di Kabupaten Sukabumi, Kampung Pulo di Kabupaten Garut, Kampung Kuta di Kabupaten Ciamis, Kampung Kaputihan di Kabupaten Cirebon, Kampung Cikondang di Kabupaten Bandung, Kampung Dukuh di Kabupaten Garut, Kampung Urug di Kabupaten Bogor, Kampung Banceuy di Kabupaten Subang, dan Kampung Mahmud di Kabupaten Bandung.

Secara umum dapat diungkapkan bahwa warga komunitas adat yang ada di Jawa Barat tersebut mendukung kebudayaan Sunda. Ajip Rosidi dalam E.S. Ekadjati (1984: 129) menuturkan "Secara umum dapat dikatakan bahwa yang disebut orang Sunda adalah mereka yang sehari-hari mempergunakan bahasa Sunda dan menjadi pendukung Kebudayaan Sunda." Lebih lanjut Ajip mengatakan bahwa masyarakat Sunda merupakan masyarakat terbuka yang mudah sekali menerima pengaruh dari luar, tetapi juga kemudian menyerap pengaruh itu sedemikian rupa sehingga menjadi miliknya sendiri.

Tentang suku bangsa Sunda, Harsoyo menjelaskan: "Secara antropologi budaya dapat dikatakan, bahwa yang disebut suku Sunda adalah orang-orang yang secara turun temurun menggunakan bahasa ibu bahasa Sunda serta dialeknya di Jawa Barat, daerah yang juga sering disebut Tanah Pasundan atau Tatar Sunda." (Harsoyo dalam Koentjaraningrat, 1982: 300).

Apabila menyimak paparan mengenai unsur-unsur budaya yang hidup dan berkembang pada warga komunitas adat seperti terurai pada hasil dokumentasi dan kajian para peneliti BPSNT Bandung, dapat diungkapkan bahwa bahasa Sunda mempunyai dialekdialek, yang masing-masing mempunyai kosa kata yang khas, lagu bicara sendiri, bahkan susunan kalimat tersendiri; tetapi dapat saling memahami satu sama lain. Dialek-dialek yang dikenal misalnya dialek Cirebon, dialek Banten, dialek Kuningan, dialek Majalengka, dan dialek Bandung. Pada Kongres Bahasa Sunda 1926 telah diputuskan bahwa yang disebut bahasa Sunda Umum ialah bahasa Sunda dialek Bandung (Ajip Rosidi dalam E.S. Ekadjati, 1984 : 137).

Selain bahasa Sunda sebagai identitas kesundaan, ciri lain adalah apabila dua orang Sunda yang tidak saling mengenal bertemu, maka yang pertama kali mereka percakapkan 
adalah menelusuri panca kaki, yakni mengetahui asal daerah masing-masing dan mencari orang yang paling mereka kenal. Kemudian mencoba mencari hubungan masing-masing dengan orang tersebut. Betapa pun selalu diusahakan supaya ada titik pertemuan dengan orang yang diajak bicara.

Pada kalangan orang Sunda ada suatu kepercayaan bahwa perubahan sosial dan politik pada masa yang akan datang terjadi sesuai dengan yang telah diramalkan oleh para karuhun (leluhur atau nenek moyang). Kepercayaan akan ramalan di kalangan orang Sunda pada masa lalu biasa disebut dengan uga. Sementara itu di kalangan masyarakat Jawa kepercayaan semacam itu disebut Ramalan Jayabaya.

Uga merupakan suatu tujuman atau ramalan (prophecy) yang menyangkut kehidupan sosial dan politik di kalangan orang-orang Sunda. Dalam pengertian $u g a$, juga terkandung faktor "waktu" (yang sudah diramalkan oleh karuhun atau nenek moyang). Sebagai suatu ramalan, maka uga itu cenderung untuk membicarakan hal-hal yang bersifat duniawi. Oleh karena itu, uga lebih mencerminkan pandangan hidup manusia sebagai pribadi, hubungan manusia dengan lingkungan masyarakatnya, dan hubungan manusia dengan alam atau lingkungan hidupnya. Contoh uga yang dikenal masyarakat Sunda adalah $U g a$ Bandung, Uga Banten, Uga Galunggung, dan Uga Kawasen.

Hasil kajian para peneliti BPSNT Bandung mengungkapkan bahwa warga komunitas adat merupakan contoh komunitas yang berusaha menyesuaikan diri dengan lingkungan alam dan berupaya mempertahankan kondisi lingkungan alamnya dengan tetap menaati aturan adat warisan para leluhur sehingga setiap komunitas adat tersebut memiliki ciri khas yang membedakannya dengan masyarakat lain. Para pendahulu mereka (leluhur) mengembangkan aturan-aturan adat yang direalisasikan pada beberapa tabu/pamali/larangan/buyut.

Aturan-aturan adat tersebut mempunyai makna atau fungsi yang sangat luas. Aturan tersebut juga berfungsi sebagai mekanisme kontrol dalam kebudayaan yang menahan dilakukannya eksploitasi alam secara semena-mena, membuat masyarakat tetap sederhana, tidak hidup berlebihan, dan tetap memegang prinsip kebersamaan sehingga keseimbangan lingkungan, baik fisik maupun sosial, dapat dipertahankan. Mekanisme itu diselimuti dengan sanksi moral, sehingga keadaan lingkungan relatif stabil dalam jangka waktu relatif lama.

Kajian menarik tentang komunitas adat ini antara lain mencuatkan kenyataan bahwa pada warga komunitas adat, sulit untuk memisahkan antara kehidupan yang bersifat agama (hampir semuanya penganut Islam) dengan yang bersifat adat karena masing-masing saling mempengaruhi. Misalnya di Kampung Dukuh biasa dilakukan upacara jaroh. Agama menganjurkan agar umatnya selalu ingat akan mati, dengan demikian akan selalu ingat Yang Maha Pencipta karena akan kembali kepadaNya. Masyarakat merealisasikan hal tersebut dengan berziarah ke makam, tetapi ternyata adat ikut berperan dalam tata cara ziarah tersebut yaitu berlakunya peraturan yang tidak ada kaitannya dengan aturan-aturan agama, misalnya harus dilakukan tiap hari Sabtu, pegawai negeri dan pedagang dilarang berziarah serta di tiap hambalan (trap) dilakukan 
sungkem (posisi menyembah, telapak tangan dilekatkan di depan dada, wajah menunduk).

Uraian di muka merupakan salah satu bukti bahwa dalam beberapa kasus adat, tampak terdapatnya pertentangan antara adat istiadat dengan ajaran agama Islam. Pada salah satu kampung adat terdapat aturan yang melarang anggota masyarakat untuk berdagang, misalnya. Menurut ajaran Islam, berdagang sama sekali tidak dilarang karena Nabi Muhammadsendiripernahberdagang. Bila ditinjau lebih jauh, tabu untuk berdagang sebenarnya bukanlah kehendak mereka untuk menentang syariat Islam, tetapi berasal dari larangan / tabu untuk berbuat bohong dan tidak jujur terhadap sesama manusia. Larangan berbuat bohong dan tidak jujur yang bersifat abstrak, mereka konkritkan dalam bentuk tabu untuk berdagang sebab dalam berdagang, menurut mereka, kecenderungan untuk berbohong dan tidak jujur selalu ada dan sulit untuk dihindarkan.

Konkrit memang merupakan salah satu sifat dari cara berpikir masyarakat manusia. Konkrit di sini artinya memanipulasi hal-hal yang bersifat abstrak (tidak nyata atau samar) menjadi nyata dan tegas. Cara berpikir demikian umumnya telah diajarkan oleh cikal bakal atau para pendiri kampung yang menyusun aturannya sedemikian rupa sehingga mudah dimengerti.

Larangan-larangan seperti tabu bepergian atau mendirikan bangunan pada saat larangan sasih, sebenarnya bermakna taat dan disiplin terhadap waktu. Masyarakat diharapkan bisa memanfaatkan waktu dengan sebaikbaiknya, menggunakan kesempatan seefisien mungkin sehingga tidak ada waktu yang terbuang percuma.
Tabu-tabu yang berlaku dalam kehidupan sehari-hari pada prinsipnya berfungsi untuk menghindarkan konflik, perpecahan,pertentangandankrisismoral. Hampir setiap komunitas adat selalu menganjurkan untuk tidak hidup mewah atau mengejar kesenangan duniawi. Dengan kata lain, warga komunitas adat mengagungkankesederhanaan, sederhana dalam memenuhi kebutuhan hidupnya. Kesederhanaan ini tampak dalam cara berpakaian, saling menyapa dengan akrab, serta tidak saling berlomba untuk memperbagus rumahnya. Hal tersebut menimbulkan pergaulan yang rukun, akrab, dan erat dalam suasana tenang dan tenteram.

Ketenteraman hidup tampaknya menjadi motif utama dalam hidup bermasyarakat menurut pandangan hidup warga komunitas adat. Mereka tidak suka konflik, karena konflik akan menimbulkan keonaran dalam masyarakat, sehingga ketenteraman akan terganggu. Supaya bisa hidup tenteram, maka dalam pergaulan orang harus bertindak hartihati, harus waspada, matang dan penuh perhitungan dalam melakukan sesuatu serta menghargai pendapat dan perasaan orang lain.

Selain menjaga hubungan yang erat antara manusia dengan manusia sebagai anggota masyarakat dan sesama makhluk Allah, untuk menjaga ketenteraman dan kedamaian, mereka juga memelihara hubungan yang erat dengan dunia gaib. Pada pokoknya, warga komunitas adat membagi yang gaib ke dalam tiga golongan, yaitu : Allah nu Maha Kawasa, karuhun atau roh nenek moyang, dan makhluk-makhluk halus yang menghuni tempat tertentu.

Sebagai penganut agama Islam, warga komunitas adat di Jawa Barat 
meyakini bahwa Gusti Nu Maha Suci (Tuhan Yang Maha Suci) adalah pencipta alam semesta beserta seluruh isinya dan merupakan kekuatan tertinggi yang berkuasa untuk menghukum hamba-Nya yang melanggar larangan serta memberi ganjaran / pahala kepada hamba-Nya yang taat menjalankan perintah. Untuk tetap menjalin hubungan yang erat dengan Tuhannya, masyarakat selalu berupaya untuk selalu mematuhi syara (syariat atau hukum Islam).

Warga komunitas adat juga mempercayai bahwa roh nenek moyang dengan kekuatan gaibnya masih tetap memelihara dan mengawasi kehidupan masyarakat, bahkan masih dapat menghukum pelanggar ketentuannya yang berupa tabu atau larangan. Oleh karena pentingnya peranan karuhun bagi kehidupan masyarakat, maka mereka yakin bahwa hanya dengan menaati segala peraturan yang dibuat oleh karuhun, kehidupan ini dapat berjalan lancar. Tabu-tabu yang berlaku selalu ditaati dengan penuh pengabdian.

Untuk tetap menjalin hubungan yang erat dengan arwah para leluhur, merekaselalumenyelenggarakanupacaraupacara adat dengan khidmat dan sakral. Kekhidmatan upacara tercermin dari tata cara yang dilakukan, di antaranya adalah berlakunya beberapa tabu yang berfungsi menjaga kesucian, kekhidmatan dan kesakralan upacara. Pada saat upacara menurut mereka, yang dituntut bukan paksaan tetapi kepasrahan, menyerah dan mendekatkan diri kepada Yang Maha Kuasa melalui para karuhun mereka.

Makhluk gaib lainnya adalah makhluk-makhluk halus yang menghuni tempat-tempat tertentu. Warga komunitas adat percaya bahwa alam ini dihuni oleh berbagai macam makhluk halus selain manusia, tumbuhan, binatang, dan benda-benda mati. Makhluk-makhluk halus tersebut suka mengganggu kehidupan mereka bila merasa diabaikan keberadaannya atau hubungan yang masih hidup dengan yang gaib (makhluk halus) tidak dijaga dengan baik. Oleh karena itu, untuk menjaga keselarasan hubungan dengan makhluk halus ini, maka di tempat-tempat tertentu sering dipersembahkan sesajen atau pada saat tertentu sering dilakukan upacara, selamatan atau syukuran.

Warga komunitas adat secara sadar telah menyatakan sikap kompromis terhadap makhkluk-makhluk halus yang berada di sekeliling mereka. Misalnya, seseorang yang ingin membangun atau memperbaiki rumah, sebelum pembangunan atau perbaikan rumah dilaksanakan terlebih dahulu akan meminta izin dan perkenan dari makhluk halus yang mungkin telah lebih dahulu menempati atau tinggal di tempat tersebut. Permintaan izin tersebut dilakukan dengan jalan mengadakan selamatan dan upacara yang di dalamnya terdapat acara pemberian sesajen kepada makhluk halus atau roh nenek moyang supaya tidak mengganggu (marah) dan mendatangkan malapetaka. Demikian juga setelah rumah selesai dibangun atau diperbaiki, mereka mengadakan syukuran yang ditujukan kepada karuhun dan Tuhan Yang Mahaesa atas lancarnya pembangunan atau perbaikan rumah tersebut.

Warga komunitas adat percaya terhadap adanya makhluk-makhluk halus yang tidak tampak. Kepercayaan tersebut timbul untuk menjawab dan menerangkan hal-hal yang tampak ganjil dan tidak dapat dihindarkan, sehingga sesuai dengan imajinasi yang dipunyainya, 
mereka berusaha membuka hubungan dengan makhluk-makhluk halus tersebut. Malefijt mengatakan bahwa sebagai polapola kebudayaan yang sistematis, religi berfungsi sebagai sumber penjelasan (1968 : 8). Lebih lanjut Clifford Geertz menjelaskan, di samping rasa heran dan takjub menghadapi teka-teki hidup ini, semuanya melukiskan kemenangan kebudayaan atas alam, dan keunggulan manusia atas bukan manusia, sehingga semuanya dapat diatur sesuai imajinasi manusia yang bersangkutan (1981:36).

\section{Ketua adat: abah (Kasepuhan Sinarresmi-Sukabumi) (a), olot (Kampung Urug-Bogor) (b), kuncen/ olot (Kampung Cikondang) (c), kuncen (KampungNaga-Tasikmalaya) (d), abah (Kasepuhan Ciptamulya) (e), kuncen/mama (Kampung Dukuh- Garut) (f)}

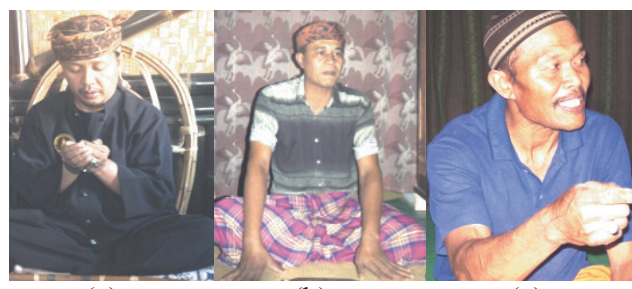

(a)

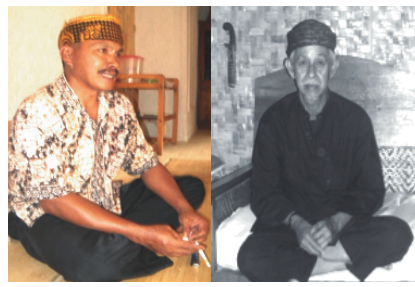

(d) (c)

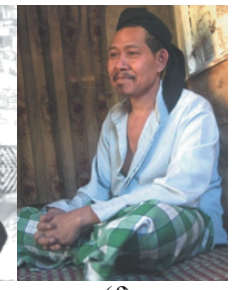

(f)
Sumber : Dok BPSNT Bandung, 2011

Ketergatungan warga komunitas adat pada kuncen, abah, olot, atau puun (pemimpin / ketua adat) sebagai orang yang dianggap mempunyai kelebihan dari anggota masyarakat lainnya, berkaitan erat dengan adat istiadat berupa aturan permainan, yang direalisasikan dalam beberapa tabu. Ketua adat dianggap sebagai orang yang mampu mewakili untuk berhubungan dengan leluhur, sehingga segala sesuatu yang menjadi keinginan masyarakat bisa disampaikan dengan perantaraan ketua adatnya (dianggap sebagai perantara tunggal). Demikian pula sebaliknya, pesan yang ingin disampaikan oleh leluhur untuk masyarakatnya bisa diterima ketua adat melalui firasat-firasat yang dirasakan pada waktu melakukan maneja (meditasi). Pesan itu dapat juga diterima pemimpin / ketua adat melalui mimpi atau gejala-gejala alam yang kemudian ditafsirkan olehnya.

Kewibawaan pemimpin adat berpengaruh besar dalam kelangsungan adat istiadat warga komunitas adat, sehingga apa yang dianggap baik olehnya akan baik pula menurut masyarakatnya dan apa yang dikatakan tidak baik olehnya akan tidak baik pula bagi masyarakatnya.

Pelaksanaan pembangunan di pemukiman warga komunitas adat relatif belum bisa berjalan dengan lancar. Hal itu disebabkan oleh keadaan masyarakat yang masih menganggap bahwa adat istiadat warisan nenek moyang masih mempunyai nilai bagi mereka. Dalam hal iniketuaadatmasihtetapmempertahankan sikap tradisionalisme sebagai bukti ketaatan terhadap ketentuan yang telah digariskan oleh nenek moyang.

Salah satu bukti ketaatan terhadap ketentuan warisan karuhun adalah tidak berubahnya bentuk bangunan tempat tinggal (rumah) penduduk. Rumahrumah atau bangunan tempat tinggal penduduk di hampir seluruh kampung adat berbentuk panggung, membujur 
dari barat ke timur, dan menggunakan bahan pembangunan rumah yang sama (berarsitektur tradisional). Secara sepintas, tampaknya tidak ada perbedaan sama sekali antara rumah yang satu dengan yang lainnya.

Untuk membangun sebuah rumah, mereka mengikuti pola-pola yang telah berlaku turun-temurun karena rumah menurut mereka bukan hanya sebagai tempat berlindung dari terik matahari, binatang buas, dan hujan. Rumah dianggap sebagai pakaian yang keberadaannya bisa mencerminkan keluarga yang menghuninya. Rumah yang baik menurut mereka, adalah yang sederhana (berbentuk sesuai dengan ketentuan yang digariskan karuhun). Ketentuan-ketentuan warisan karuhun yang menjadi tradisi pada masyarakatmasyarakat kampung adat, tampak dalam tabu atau aturan-aturan membangun rumah yang unik.

\section{Permukiman yang asri di Kampung Naga - Tasikmalaya, terdiri atas bangunan-bangunan berarsitektur tradisional}

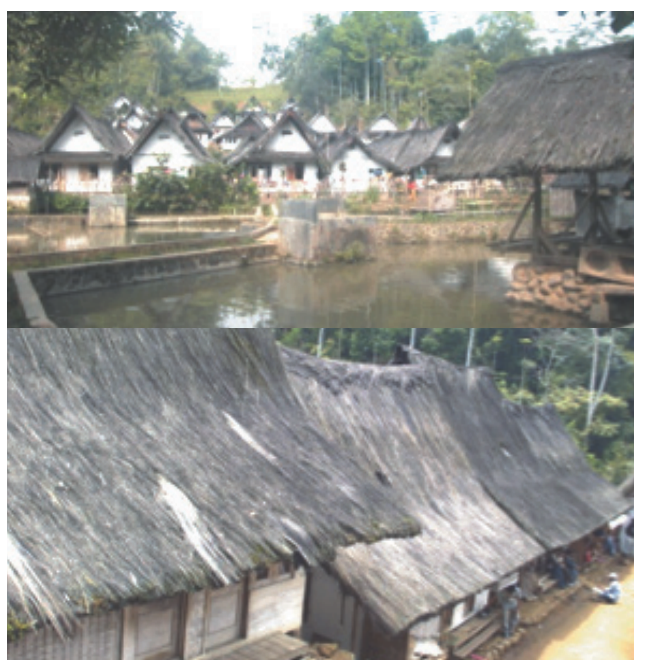

Sumber : Dok BPSNT Bandung, 2011
Beberapa tabu seperti tidak boleh membuat rumah lebih bagus daripada tetangga, dinding tidak boleh dicat atau dikapur, tidak boleh menggunakan kaca, lantai rumah harus dari bambu (palupuh), dinding tidak boleh ditembok, dan lain-lain; sebenarnya mempunyai makna agar kebersamaan tetap terjaga. Tidak ada sikap ingin berlomba dalam menggejar kemewahan. Tabu-tabu tersebut mengandung implikasi lebih lanjut, bila kebersamaan tetap terjaga, maka ketentraman akan tercipta dan menimbulkan suasana pergaulan yang mesra dan harmonis. Tidak ada yang merasa di bawah atau miskin dan sebaliknya tidak ada yaang merasa di atas, lebih dari yang lain karena merasa kaya.

Beberapa komunitas adat melarang warganya untuk menggunakan gergaji besar pada waktu membangun rumah. Tabu tersebut mengandung makna agar tidak mengeksploitasi lingkungan alam secara besar-besaran atau semena-mena. Mereka menyadari bahwa lingkungan alam memegang peranan sangat penting hampir pada semua aspek kehidupan. Oleh karena itu, bentuk interaksi antara masyarakat dengan lingkungan alamnya berdasarkan atas anggapan bahwa lingkungan alam harus diperlakukan seperti mereka memperlakukan diri sendiri dan sesama manusia. Juga, ada anggapanbahwalingkunganalam tersebut tidaklah sepenuhnya milik mereka, ada makhluk lain yang juga merasa memiliki, yaitu makhluk-makhluk halus. Dalam memanfaatkan lingkungan alam, tidak terlepas dari berbagai upacara yang pada dasarnya merupakan permintaan izin kepada makhluk-makhluk halus tersebut. Hal ini pada akhirnya akan menahan hasrat dari masyarakat untuk 
mengeksploitasi lingkungan alamnya secara semena-mena.

Arsitektur tradisional memiliki logika struktur yang kuat. Andi Siswanto (1987) menegaskan: arsitektur tradisional memang selalu bereaksi secara nalar, cerdas terhadap ekologi setempat. Hal tersebut tercermin dalam beberapa tabu yang berbunyi antara lain : suhunan berbentuk suhunan panjang, rumah harus berkolong (panggung), tidak boleh menggunakan pohon yang tumbang, dan tidak boleh memasang kayu secara terbalik.

Makna dari aturan: suhunan harus berbentuk panjang, menyiratkan soal kepraktisan yang memungkinkan pembuatan rumah tidak sulit dan berbelitbelit. Demikian juga dengan keharusan membujur dari timur ke barat. Selain berpijak pada unsur kepraktisan juga terdapat unsur kepercayaan yaitu akan datang malapetaka dan kesulitan apabila bentuk suhunan rumah menentang perjalanan matahari. Hal itu juga menyiratkan keselarasan dengan gerak kehidupan yang dilambangkan dengan perjalanan matahari yaitu terbit dari timur dan tenggelam di barat.

\section{Rumah-rumah dengan} suhunan panjang di Kampung Gede Kasepuhan Ciptagelar-Sukabumi (a), Kampung Kuta-Ciamis (b), Kampung Naga-Tasikmalaya (c), dan Kampung Dukuh-Garut (d)

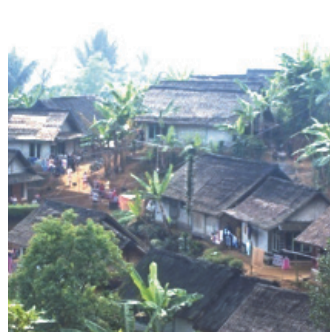

(a)

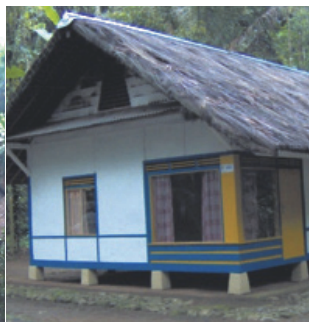

(b)

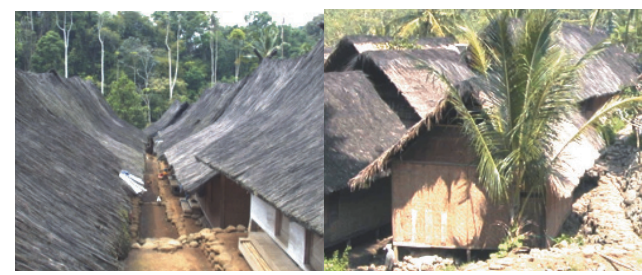

(c)

(d)
Sumber : Dok. BPSNT Bandung, 2011

Sifat arsitektur tradisional yang cerdas, tercermin pula dalam aturan yang berbunyi: tidak boleh menggunakan pohon yang tumbang untuk bahan bangunan rumah. Pohon bisa tumbang karena lapuk atau terserang badai dan apabila dijadikan bahan bangunan, kemungkinan cepat rusak atau rapuh sangat besar. Demikian juga dengan larangan untuk memasang kayu secara terbalik karena secara logika, kekuatan kayu makin kuat ke pangkalnya dan sebaliknya makin kecil atau makin berkurang kekuatannya ke bagian ujung.

\section{Kolong rumah di Kampung Naga (a,b), Kampung Kuta (c), dan Kampung Pulo (d)}

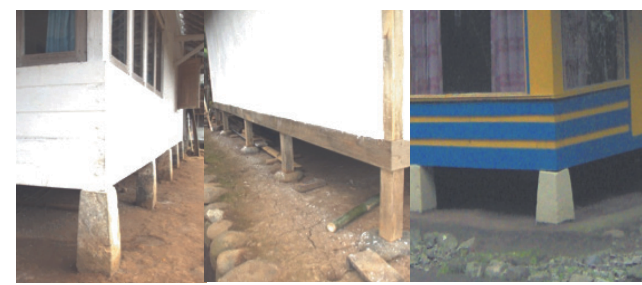

(a)

(b)

(c)

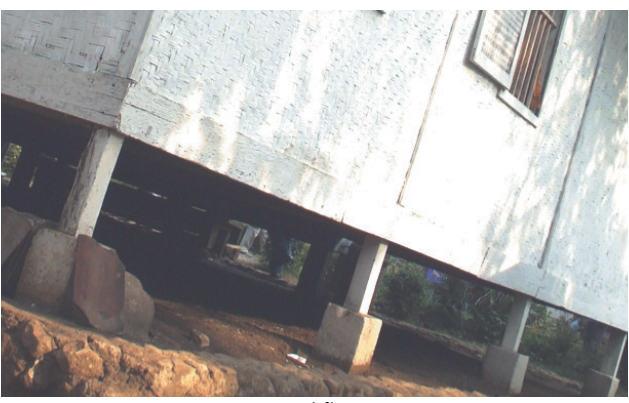

(d)

Sumber : Dok BPSNT Bandung, 2011 
Keharusan rumah berkolong mempunyai konotasi yang luas karena selain berkaitan erat dengan sistem pengetahuan praktis (pada mulanya untuk menjaga diri dari bahaya atau serangan binatang buas, iklim, dan tempat sirkulasi udara dari dalam keluar rumah melalui lubang-lubang palupuh), juga ada kaitannya dengan sistem kepercayaan bahwa dunia ini terbagi menjadi 3 bagian yaitu : dunia bawah, dunia tengah, dan dunia atas. Dunia bawah adalah bumi dan dunia atas adalah langit. Dunia tengah adalah pusat alam semesta, tempat segala makhluk berkembang dan mempertahankan kehidupan. Oleh karena itu, rumah tempat manusia melangsungkan kehidupannya harus terletak di tengah-tengah, tidak di dunia bawah (bumi) maupun di dunia atas (langit). Dengan demikian rumah tersebut harus mempunyai kolong yang berfungsi sebagai pemisah antara rumah secara keseluruhan dengan dunia bawah.

Dengan adanya tabu atau aturan-aturan membuat rumah seperti tersebut di atas, pemukiman warga komunitas adat tersusun atas bentukbentuk bangunan rumah yang seragam, teratur dan rapi. Walaupun bentuk konstruksinya sederhana, rumah-rumah tersebut nampak kuat dan kokoh dengan bertumpu pada batu alam. Bangunan yang mempunyai konstruksi demikian merupakan bangunan yang tahan gempa karena seluruh bagian yang merupakan kesatuan diletakkan di atas batu, akan bergeser seluruhnya bila ada gempa (Irawan Maryono, 1985 : 62).

Konsep pengudaraan (ventilasi) dikenal pula, berfungsi untuk mencegah panas dan mengatasi kelembaban ruangan. Udara yang mengalir bergantian menyebabkan pertukaran udara di dalam ruangan berjalan baik. Konsep ruang terbuka di bawah atap (pada beberapa kampung adat hanya tertutup abig setengahnya), digunakan untuk pengudaraan silang (cross ventilation), mengganti udara dari dalam ruangan dengan udara segar dari luar. Selain itu, konsep dinding bernafas juga digunakan (diatur dengan tabu untuk mengecat atau mengapur dinding). Jendela dan pintu, serta lantai bambu (palupuh yaitu bambu yang dicabik-cabik sehingga ada bagian yang berlubang-lubang); berfungsi juga sebagai tempat pertukaran udara. Dengan demikian, unsur kenyamanan thermal tidak terabaikan dalam pembentukan rumah.

Konsepsi yang tersirat dalam rumah warga komunitas adat merupakan konsepsi yang bijaksana karena berpijak pada keserasian dan penghargaan terhadap lingkungan. Bahan-bahan pembentuk rumah, didapat dari alam sekeliling dengan penggunaan sumber alam yang bijaksana artinya eksploitasi yang dilakukan terbatas pada penggunaan seperlunya dan tidak semena-mena karena dibatasi dengan tabu atau larangan yang secara tidak langsung mengatur masyarakat untuk bersikap arif terhadap lingkungan alamnya.

Penghargaan terhadap alam yang menyebabkan penggunaan sumber daya alam dengan arif, membuat kondisi kampung berhawa sejuk. Kenyataan tersebut telah mempertebal keyakinan mereka bahwa di samping kegunaan yang bersifat sakral (dengan menaati tabu atau aturan-aturan warisan nenek moyang yang berlaku turun temurun), lingkungan alam juga mepunyai kegunaaan yang bersifat profan atau nyata.

Dari ulasan-ulasan di atas, dapat diketahui bahwa tabu atau aturan- 
aturan dalam membangun rumah yang merupakan warisan para karuhun, sebenarnya mempunyai makna atau fungsi yang sangat luas. Selain berfungsi untuk membuat rumah-rumah penduduk sama bentuk, struktur dan bangunan rumahnya, juga menghindarkan masyarakat dari bahaya perpecahan, konflik, pertentangan dan krisis moral. Lebih jauh lagi, tabu berfungsi juga sebagai mekanisme kontrol dalam kebudayaan yang menahan dilakukannya eksploitasi alam secara semena-mena. Mekanisme ini diselimuti dengan sanksi-sanksi moral dan keagamaan, sehingga keadaan lingkungan alam dan fisik relatif stabil dalam jangka waktu yang cukup lama. Otomatis, jika mekanisme itu tetap dipertahankan maka arsitektur tradisional rumahrumah warga masyarakat relatif tetap dan stabil.

\section{PENUTUP}

Filsuf, cendekiawan, pujangga dan penyair senantiasa menuturkan dan mendefinisikan bahwa segala sesuatu di dunia ini berubah. Suatu kodrat yang tidak dapat dibendung. Setiap perubahan akan diikuti kecenderungan mencari keseimbangan, sehingga lahir wujud baru. Bila terjadi perubahan pada pola berpikir, maka pola berpikir lama akan tetap mendasari perubahan tersebut.

Demikian pula yang terjadi pada kebudayaan warga komunitas adat. Perubahan yang tampak nyata antara lain dalam seni bangunan atau lebih tepatnya arsitektur rumah. Perubahanperubahan tersebut pada umumnya terjadi karena berubahnya sumber daya alam, kemajuan ilmu pengetahuan dan teknologi, serta berubahnya situasi dan kondisi masyarakat karena populasi yang terus bertambah.

Populasi yang terus bertambah, menyebabkan kampung gede/kampung induk tempat tinggal warga komunitas adat semakin padat dengan bangunan rumah (tempat tinggal). Pada kampungkampung induk, penambahan bangunan rumah umumnya tidak dimungkinkan lagi karena sudah terlalu padat dan tidak ada lahan kosong yang bisa ditempati. Bagi penduduk yang mempunyai biaya lebih, bisa menempati tanah di sekeliling kampung dengan membeli lahan kosong sebagai tempat untuk mendirikan rumah. Akan tetapi bagi penduduk yang belum bisa membeli lahan untuk lokasi rumahnya, cukup menumpang pada rumah orang tua atau saudaranya yang mengakibatkan bertambahnya ruangan pada rumah orang tua atau saudaranya tersebut. Oleh kareana itu, ruanganruangan yang ada (kamar-kamar) pada sebuah rumah kadang-kadang menjadi semakin sempit karena dibagi dua atau disekat.

Perubahan, tidak hanya terjadi pada bangunan atau arsitektur rumah tetapi juga terdapat pada beberapa perlengkapan hidup sehari-hari. Walaupun demikian, tidak seluruh penduduk melakukan perubahan dengan kadar yang sama. Juga, hanya beberapa warga yang melakukan perubahan tersebut, itu pun kadangkadang dilakukan dengan sembunyisembunyi agar anggota masyarakat lain tidak mengetahuinya. Hal tersebut menunjukkan bahwa masyarakat masih menjunjung tinggi ketentuan yang telah digariskan nenek moyangnya.

Dalam berbagai keadaan, masyarakat selalu mencoba untuk menaati tradisi yang berlaku dan berusaha menghindarkan diri dari pelanggaran 
atas tabu. Apalagi bagi masyarakat yang tinggal di kampung induk, misalnya dukuh dalam, kampung gede, atau kajeroan, tradisi yang telah berlaku turun-temurun masih tetap ditaati dan dijalankan dengan penuh kesungguhan. Oleh karena itu, walaupun tidak bisa ditentukan secara pasti, akan tampak adanya perbedaan kadar perubahan (pelanggaran ) antara masyarakat yang tinggal di kampung induk dengan yang tinggal di panamping / babakan / kampung baru, dan pagar pembatas atau garis / batas imajiner, agaknya betul-betul merupakan filter atau penyaring kemapanan adat istiadat walau tidak bisa dipungkiri bahwa perubahan (pelanggaran) dalam skala kecil bisa juga terjadi di kampung induk.

Perubahan-perubahan yang dilakukan masyarakat kampungkampung adat seperti tampak dalam contoh di atas, ternyata tidak bersifat total karena inti atau dasar kebudayaannya tidak mengalami perubahan, atau perubahan yang terjadi tidak mengubah sifat pokok dari kebudayaan mereka. Ditinjau dari sikap dan tingkah laku masyarakat sehari-hari, misalnya, mereka masih tetap sederhana, menghindari hidup berlebihan dan tetap memegang prinsip kebersamaan. Hal itu antara lain tercermin dalam arsitektur rumah mereka yang masih bercirikan tradisional dengan masih tampaknya sifat-sifat asli yang berasal dari ketentuan yang telah digariskan karuhun, yaitu kesamaan dalam bentuk, struktur, arah membujur, arah menghadap, dan bahan bangunan rumahnya.

Kehidupan sosial budaya dan gejala-gejala perubahan yang berhasil diidentifikasi serta dapat dijadikan permasalahan atau landasan bagi kajian lebih lanjut terkait eksistensi dan strategi adaptasi komunitas adat, antara lain adalah :

1. Warga komunitas adat berupaya untuk tidak melepaskan diri dari belenggu adat yang selama ini dipatuhi dan dijalankan dengan penuh kesungguhan akibat beberapa faktor, antara lain kehidupan mereka relatif tenang dan tenteram, serta merasa senasib sepenanggungan karena merasa satu keturunan. Kuncen/abah/olot dianggap keturunan dari karuhun mereka, oleh sebab itu selalu menjadi panutan dan pimpinan yang kharismatik. Aturan adat dan pola kebiasaan warisan leluhur masih dipegang teguh oleh warga komunitas adat. Aturanaturan adat tersebut masih memiliki peran dan fungsi yang nyata dalam menciptakan keselarasan, keserasian, dan keseimbangan hidup masyarakat secara keseluruhan.

2. Strategi adaptasi warga komunitas adat terhadap kondisi fisik lingkungan menarik untuk diamati, mengingat kelengkapan pemukiman mereka masih dianggap sederhana apabila dibandingkan dengan pemukiman masyarakat sekitarnya. Penduduk membuat rumah dengan bahan-bahan yang sederhana, terdiri atas rangka kayu atau bambu, dinding bilik (anyaman bambu), dan atap dari anyaman daun alang-alang). Keseluruhannya dapat dibongkar, dipasang atau dipindahkan dengan tidak terlalu sulit karena tidak permanen.

3. Mengingat pentingnya peran dan fungsi kuncen/ketua adat/ olot/abah sebagai stabilisator kehidupan warga komunitas adat, aparat / instansi terkait 
hendaknya selalu berhubungan dengan ketua adat tersebut dalam upaya mensosialisasikan dan merealisasikan program-program pembangunan.

4. Masalah lain yang menarik adalah imbas perkembangan ilmu pengetahuan dan teknologi. Gejala perubahan yang paling mudah diketahui dan diamati adalah adanya perubahan tempat tinggal. Hampir di setiap pemukiman warga komunitas adat ada beberapa keluarga yang merenovasi rumahnya dalam bentuk permanen yakni dinding tembok, lantai keramik, dan atap genting. Alat elektronik rumah tangga seperti TV, kulkas, dan pemanas nasi sudah digunakan oleh sebagian warga komunitas adat.

\section{DAFTAR PUSTAKA}

Ember, Carol R. dan Melvin Ember. 1990.

"Konsep Kebudayaan" dan "Teori dan Metode Antropologi Budaya”, dalam T.O. Ihromi, Pokok-pokok Antropologi Budaya. Jakarta: Gramedia.

Ihromi, T.O. 1980.

Pokok-pokok Antropologi Budaya. Jakarta: Gramedia.

Indonesia. Depdikbud. 1981/1982.

Arsitektur Tradisional Daerah Jawa Barat. Bandung: Proyek Inventarisasi dan Dokumentasi Kebudayaan Daerah.
Koentjaraningrat. 1974.

Kebudayaan Mentalitet dan Pembangunan. Jakarta: Gramedia.

Sucipto, Toto. 1990.

Arsitektur Tradisional Rumah Masyarakat Kampung Dukuh. Skripsi. Bandung: Jurusan Antropologi Unpad.

Warnaen, Suwarsih et. al. 1987.

Pandangan Hidup Orang Sunda seperti Tercermin dalam Tradisi Lisan dan Sastra Sunda. Bandung: Depdikbud. Proyek Penelitian dan Pengkajian Kebudayaan Sunda. 